\title{
Socio Techno Media Literature In The Spirit Of Anti Hoax, Maintaining Community Harmony In Panji Village
}

\author{
Irwan Nur ${ }^{1}$, I Putu Putra Yana Wardana ${ }^{1}$, I Wayan Mudana ${ }^{1}$ \\ irwannur@undiksha.ac.id, putrayana@undiksha.ac.id \\ ${ }^{1}$ Universitas Pendidikan Ganesha, Indonesia
}

\begin{abstract}
The development of information that is so rapid and without boundaries has a positive and negative impact on people's social life. Without a media literacy filter, any information can lead to hoaxes and affect the harmony and harmonization of the social life of the village community, especially the people in Panji village. Village communities are very vulnerable to hoax news, because their conditions are much different from urban communities in terms of education, employment and level of mastery of technological literacy. Therefore, it becomes interesting to study and research more deeply in socio-technological studies. How is the relationship between humans and humans, humans with the surrounding environment and humans with technology. From this study, it is hoped that it can add information to the community in Panji Village on hoax information, sort out information and prevent hoaxes from developing into damaging community harmony and harmonization. So far, people find it difficult to distinguish between hoaxes and true news, people stutter in using technology properly and correctly, and do not know how to deal with hoaxes themselves. This study uses the method of observation conducted in the village of Panji. Questionnaires were distributed through those who were willing to fill in the no wa data of the Panji village community, resulting in the community being aware and agreeing on the importance of positive and negative socio-techno impacts in maintaining
\end{abstract}

Keyword: socio techno; media literature; anti hoax; harmony

\section{Introduction}

This research helps open up the insight of the research team and the target community, namely the people in Panji village, that the importance of media literacy in counteracting hoaxes is the negative impact of socio-techno in order to maintain harmony and harmony. The development of information that is so rapid and without boundaries has a positive and negative impact on people's social life. Without a media literacy filter, any information can lead to hoaxes and affect the harmony and harmonization of the social life of the village community, especially the people in Panji village. Village communities are very vulnerable to hoax news, because their conditions are much different from urban communities in terms of education, employment and level of mastery of technological literacy. Therefore, it becomes interesting to study and research more 
deeply in socio-technological studies. How is the relationship between humans and humans, humans with the surrounding environment and humans with technology. From this study, it is hoped that it can add information to the community in Panji Village on hoax information, sort out information and prevent hoaxes from developing into damaging community harmony and harmonization. So far, people have difficulty distinguishing hoaxes and true news, people stutter in using technology properly and correctly, and do not know how to deal with hoaxes themselves. improve media literacy to stimulate socio-techno in counteracting hoax news that can affect community harmony and harmonization in Panji village.

Socio-technology is a new field of study that seeks to see the influence of technological evolution in social life. Along with the birth of postmodernism, people began to abandon the Aristotelian division in scientific disciplines, for example with the birth of the study of complexity, the theory of pattern language in architecture and others. Socio-technology seems to have been born in such a spirited environment, besides that there is a direct concern over the 'wildness' of technological developments which often raises questions related to morality and social life. Socio-technology has special relevance in developing countries such as Indonesia and many other countries. (Wikipedia). Socio-technology is a science which is a relation of social sciences (social sciences) with technology (engineering). Technology is seen from various perspectives, but the point is to try to be critical of the existence of technology which is usually seen as positivistic deterministic, especially in countries that "seem" to be perpetual consumers of technology such as Indonesia. According to Filino Harahap (Mangunwijaya, 1983) technology is a systematic application of scientific knowledge for practical purposes. These knowledges are accumulated in technical and intellectual abilities which are practically applied in creating products (goods and services) for the needs of mankind. In general, the definition of sociotechnology is an epistemology of the development of science and technology from the point of view of social and human aspects. This study has a function and role to transform society into a critical, creative, and innovative knowledge society (Pikiran Rakyat, 29 August 2001). Sociotechnology itself tries to examine further about the relationship or relationship between humans and technology. This study is related to the implications of technology on aspects of people's lives and livelihoods - how to manage the impact and role of technology in increasing the degree of society on the one hand, and how society's attitude and role should be in accepting the function of technology on the other (Sinaga , 2001). The relationship or relationship between social life and technology is a benchmark for how technology can play an important role in how technology can play a role and be applied to everyday life. Various activities of human life using technology such as computers: banking, trade, industry, transportation, hospitals, education, arts, research, entertainment, defense and security, communication. Sophisticated technology is closely related to all work in everyday life. This will result in both positive and negative impacts. The positive impacts that occur because of technology that supports social aspects include: Better communication, 2. Fast \& secure data transportation, 3. Work completed faster \& more accurately, 4. Labor efficiency. While the negative impacts are: 1. Humans depend on technology, 2. Loss of work because technology becomes faster \& more thorough, 3. Hackers who destroy data on computers even though they have passwords, 4 . Hoax 
Literacy which in English comes from the Latin litera (letter) which means it involves mastering writing systems and the conventions that accompany them. However, literacy is primarily concerned with language and how it is used. The written language system is secondary. When talking about language, of course it cannot be separated from talking about culture because language itself is part of culture. Thus, the definition of the term literacy must of course include elements that surround the language itself, namely the socio-cultural situation. In this regard, Kern (2000) defines the term literacy comprehensively as follows: "Literacy is the use of socially-, and historically-, and culturally- situated practices of creating and interpreting meaning through texts. It entails at least a tacit awareness of the relationships between textual conventions and their context of use and, ideally, the ability to reflect critically on those relationships. Because it is purpose sensitive, literacy is dynamic - not static - and variable across and within discourse written and spoken language, on knowledge of genres, and on cultural knowledge. (Literacy is the use of social, historical, and cultural situational practices to create and interpret meaning through texts. Literacy requires at least an unspoken sensitivity to the relationships between textual conventions and the context in which they are used and ideally the ability to reflect critically. about these relationships. Because it is sensitive to purpose, literacy is dynamic - not static - and can vary between and within communities and discourse cultures. Literacy requires a range of cognitive abilities, knowledge of written and spoken language, knowledge of genres, and cultural knowledge). From the statement above, it can be seen that literacy requires complex abilities. The knowledge of genre is knowledge of the types of texts that apply/used in the discourse community, for example, narrative texts, expositions, descriptions and others. There are seven elements that make up the definition, namely with regard to interpretation, collaboration, conventions, cultural knowledge, problem solving, reflection, and language use. These seven things are the principles of literacy. Principles of Literacy Education According to Kern (2000) there are seven principles of literacy education, namely: 1. Literacy involves interpretation The writer/speaker and the reader/listener participate in the act of interpretation, namely: the writer/speaker interprets the world (events, experiences, ideas, feelings, etc.), and the reader/listener then interprets the interpretation of the writer/speaker in terms of his or her own conception of the world. 2. Literacy involves collaboration There is a collaboration between two parties, namely the writer/speaker and the reader/listener. The intended collaboration is in an effort to reach a common understanding. The writer/speaker decides what to write/say or not to write/say based on their understanding of the reader/listener. Meanwhile, readers/listeners devote their motivation, knowledge, and experience to make the author's text meaningful. communities and cultures. It draws on a wide range of cognitive abilities, on knowledge of 3. Literacy involves conventions People read and write or listen and speak are determined by (non-universal) cultural conventions/conventions that develop through use and are modified for individual purposes. The convention here includes the rules of language both spoken and written. 4. Literacy involves cultural knowledge. Reading and writing or listening and speaking function in certain systems of attitudes, beliefs, habits, ideals, and values. So that people who are outside a cultural system are vulnerable / at risk of being misunderstood by people who are in that cultural system. 5. Literacy involves problem solving. Because words are always attached to the linguistic context and the situation that surrounds them, the acts of listening, speaking, reading, and writing involve imagining the relationships among words, phrases, sentences, units of meaning, texts. text, and worlds. Efforts to imagine / think / consider this is a form of problem solving. 6. Literacy involves reflection and self-reflection. 
Readers/listeners and writers/speakers think about language and its relationships to the world and to themselves. Once they are in a communication situation they think about what they said, how to say it, and why it was said. 7. Literacy involves the use of language. Literacy is not limited to language systems (oral/written) but requires knowledge of how language is used both in spoken and written contexts to create a discourse/discourse. From the points above, the principle of literacy education is that literacy involves interpretation, collaboration, conversion, cultural knowledge, problem solving, self-reflection, and involves the use of language.

\section{Methods}

This study uses descriptive qualitative research methods that are used to analyze social events, phenomena or circumstances. So that from this situation it can later be done to prevent hoaxes and improve media literacy in Panji Village. Description method is a method in researching the status of human groups, an object, a set of conditions, a system of thought, or a class of events in the present. Whitney (1960) argues, descriptive method is a fact-finding with the right interpretation. Descriptive research studies problems in society, as well as the procedures that apply in society and certain situations, including relationships, activities, attitudes, views and ongoing processes and the effects of an organization. phenomenon. Descriptive research aims to make a systematic, factual and accurate description, picture or painting of the facts, characteristics and relationships between the phenomena being investigated. This type of research is situation analysis research and development of existing research. Data collection combined using google meet virtual meetings and using google forms which were used as research questionnaires distributed in the wa group of the Panji village community who were willing to be research samples. Interviews conducted by researchers aimed to find out everything related to the implementation of the transfer of inactive dynamic archives. Interviews were conducted with three informants using a snowball technique where informant $\mathrm{A}$ gave a recommendation so that informant B became an informant and so on. Snowball sampling is a technique for determining the sample which is initially small in number then enlarges (Sugiyono, 2006) in-depth interview technique. Informants will be interviewed to obtain what the situation of the Panji village community is like, information literacy skills and media literacy skills of the Panji village community. In order for in-depth interviews to take place in a directed manner, an interview guide is prepared that contains main ideas related to the problem being studied. In this way the interview is expected to take place flexibly. Likewise, the information extracted is not only based on what they say, but is also accompanied by an in-depth exploration of their meaning of their speech and behavior.

\section{Result and Discussion}

From the initial presentation of the research by making a wa group with the permission of the Panji village community who were willing to take part in this research as a research sample, forty samples were agreed to hold a virtual meeting for the presentation of the research team using Google Meet. From the virtual meeting the respondents agreed verbally to answer the questionnaire that the research team had made to obtain data that would be used later in this study. 
The following are the results and implementation of the research

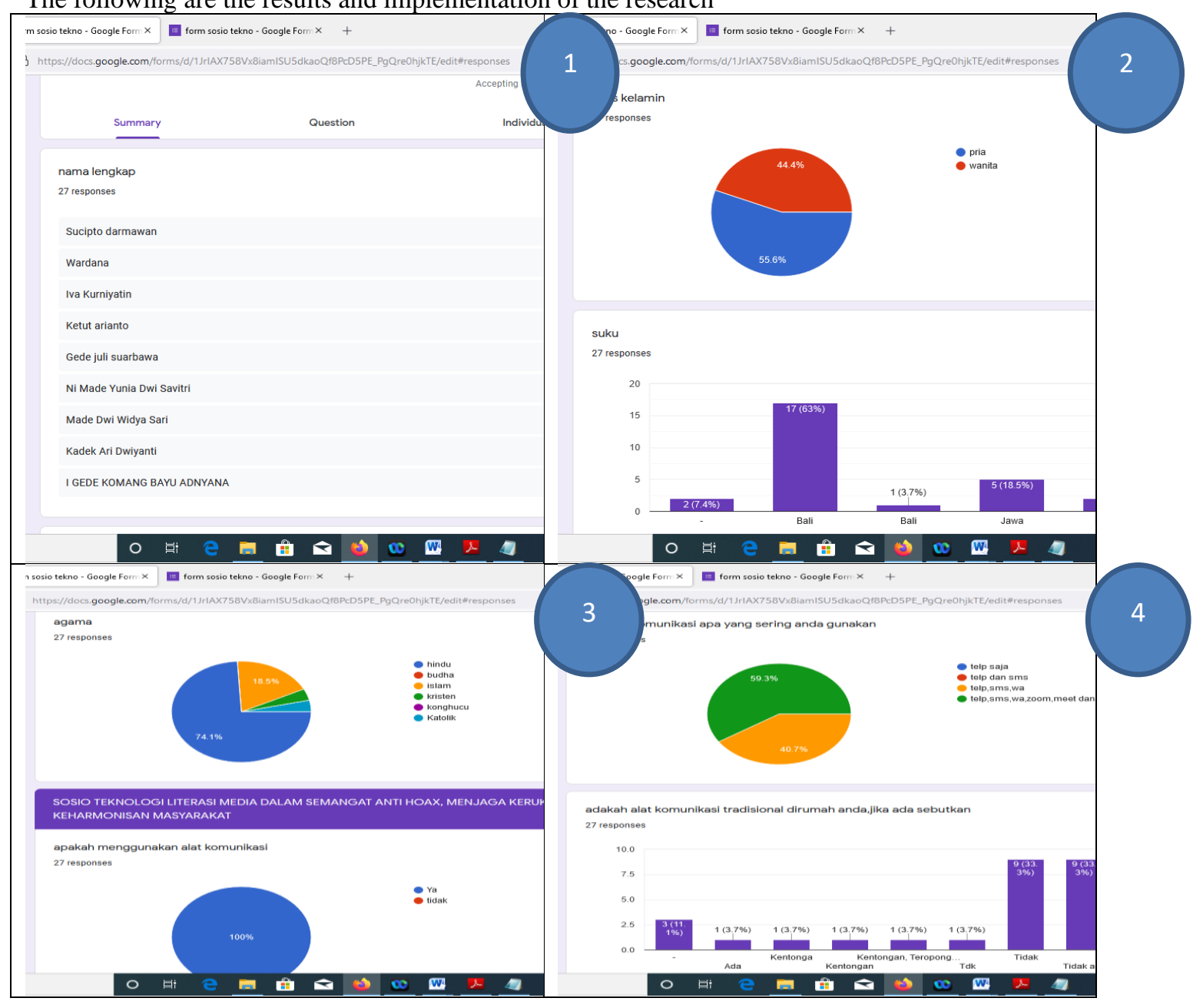




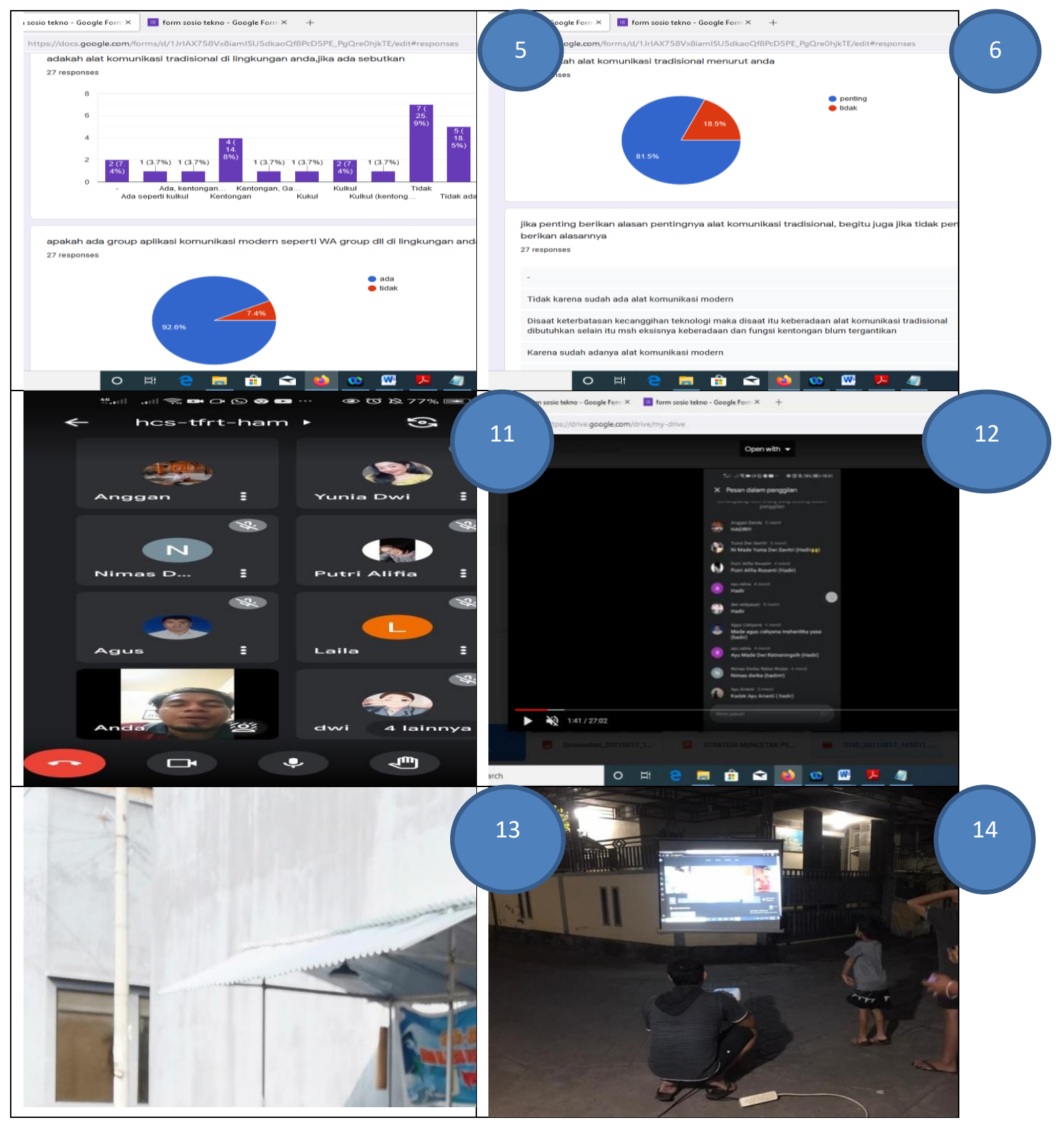


The explanation of each image according to photo numbering can be explained as follows: In the first photo, the number of respondents who were willing to fill out the questionnaire and asked for their data from the beginning of the assessment to the community asked for permission and understanding to collect research data with the permission of the Panji village head and research partners. In the second photo, the diversity of the Panji village community is used as a research sample and is willing to fill out the questionnaire. In the third photo, almost all of the questionnaire results have communication tools. The fourth photo shows a mapping of almost all Panji villagers having traditional communication tools in their respective homes. The fifth photo shows the results of this research in the form of in the Panji village environment, it is agreed that in every environment there are communication tools in the form of gongs and gongs. The sixth photo shows that almost ninety percent agree on the importance of traditional communication tools in the Panji village area and the reasons for their agreement are presented with their respective arguments.

\section{Conclusion}

Based on the results of research and data analysis conducted by researchers, it can be concluded that the Panji village community which is heterogeneous in education, ethnicity, religion and understanding of socio-techno, media literacy and hoaxes respects diversity and cares carefully for traditions, harmony and harmony. with caution in disseminating information, be careful with full awareness and responsibility for using contemporary technology such as group wa applications Suggestions that researchers can convey based on the research that has been done include: further research on socio-techno can be done with different data collection methods with more diverse samples and can be carried out in other areas that have high heterogeneity such as in Panji village.

\section{References}

[1] Burhan,Bungin (2001). Metodologi Penelitian Sosial: Format-Format Kualitatif dan Kuantitatif. Surabaya:Airlangga University

[2] Nasrullah, Rulli. 2017. Media Sosial : Perspektif Komunikasi, Budaya, dan Sosioteknologi. Bandung:Remaja Rosdakarya.

[3] Hurlock, Elizabeth B. 1980. Psikologi Perkembangan. Jakarta:Erlangga.

[4] APJII. (2014). Profil Pengguna Internet Indonesia 2014. Puskakom. Retrieved from https://www.apjii.or.id/survei2016

[5] APJII. (2016). Infografis: penetrasi dan perilaku pengguna internet indonesia, 1-34.

[6] Nasution, Z. (2011). Konsekuensi sosial media teknologi komunikasi bagi masyarakat. Jurnal Reformasi, 1, 37-41.

[7] Watie, E. D. S. (2011). Komunikasi dan media sosial ( communications and social media ). The Messenger, 3(1), 69-75. 